ORIGINAL ARTICLE

\title{
Emigration as an emancipatory project. Narratives on experiences of Polish women in Norway
}

\author{
Magdalena Herzberg \\ The Faculty of Social Sciences, University of Gdansk, Gdansk, Poland
}

Feminine migration might be considered as a way to emancipation and a great possibility to achieve both professional and private fulfillment. Migration can radically change the meaning of femininity and can strongly affect the traditional role of women. The correlation between migration and gender roles cannot be ignored when analyzing the migratory project due to their mutual in- fluence. The main aim of the research was to find out if Polish women in Norway consider their migration as a way to emancipation.

KEY WORDS

migration; emancipation; gender roles; femininity; qualitative methods 


\section{ON THE RELEVANCE OF RESEARCHING MIGRATION PROCESSES}

Modern migration movements of peoples can be described as "a constant attribute of the human race" (Bokszański, 2007, p. 243). They happen in an increasing number of European countries as well as in other parts of the world. People decide to change their place of living for a variety of reasons. Among the most important characteristics of modern migration movements are their heterogeneity, intensification, globalization, and feminization. The first characteristic refers to the variety of reasons for migrating, as well as the types and the direction of the migration. The intensification is exemplified by the constant increase of migration movements on the existing trails. Globalization, understood as the opening of work markets, causes the migration processes to develop on a scale unseen before. And finally, the observed increase in migration of women, their growing participation in various professional areas in the countries they move to and taking on the role of an independent and self-reliant player in the migration processes, are all indicators that the migration movements are being feminized.

The development of transportation methods, the ease and speed as well as relatively low costs of moving, combined with the availability of air travel, are the main factors behind the intensification of travel between countries. This development has also created a situation where spatial mobility is an inseparable part of many people's lives. According to Jack Kubitsky, who deals with psychological aspects of migration: "Never before have so many nationalities, professions and religions traveled on such a scale and as often as nowadays. In no age before this did people know as much about the world and themselves as they do now. Globalization has caused time and space to become less relevant. One of the effects of globalization is the lack of the feeling of belonging" (Kubitsky, 2012, p. 17). The essence of the sentiment is the last sentence quoted from the author: "the globalized life takes place over borders" (Kubitsky, 2012, p. 18). The quotation seems to be a great representation of the modern migration realities.

The motivations for starting migration movements vary and relate to numerous aspects of life. Some people hope to improve their material status. Others want to gain a higher position in society or to further their career. All those motivations can be summed up by a common goal - making the overall quality of their lives better and the belief that a brighter future lies in a different place in the world. According to Kawczyńska-Butrym, an additional factor influencing the likelihood of moving is "the openness of the contemporary world - the accessibility and vastness of information, the possibility to reach far away corners of the world both cheaply and fast" (KawczyńskaButrym, 2009, p. 7). Sometimes migration is meticulously planned and done with a specific goal set to be achieved in the migrating person's mind. However, it is often a journey for change, with no well-defined aims. Some people deciding to migrate cannot specify the reason why they left their home countries. They are people who are not afraid of entirely changing their whole lives, and migration is just a mean to a goal they have established for themselves.

Due to the scale of migration processes they are now considered a form of routine human behavior, a basic element of the social reality surrounding us. Considering migration processes is vital to understand this reality. Dariusz Niedźwiedzki, the author of a comprehensive theoretical and empirical study on pendular migration, describes the contemporary world as a world of migration (Niedźwiedzki, 2010).

\section{WOMEN IN CONTEMPORARY MIGRATION STREAMS}

Many scholars researching migration processes agree that women are their main players, dominating and shaping the newest migration streams. Studying the literature on the topic and directing attention to characteristics of contemporary travels, one often comes across the notion of feminization of the migration movements. Authors of scientific literature often point out that studying contemporary migration movements should not be done without considering gender as a force organizing social relations (Małek, 2011). At the same time, it cannot be overrated how important the presence of women as independent and self-reliant migrating persons is.

Back in the 1960s and at the beginning of 1970s, the phrase "migrants and their families" was obviously supposed to mean migrating men with their wives and children, migrating either with them or towards them. The progressing feminization of the migration movements allows us to look at the motivations for women's migration from an entirely new perspective (Małek, 2011).

Omission and underestimation of women in the migration streams (alongside assigning them a traditionally passive attitude towards moving) does not reflect the reality found in contemporary analyses of migration movements. It is women who are considered more capable of building unofficial networks of contacts in a new country, using their adaptive capacity, a helpful trait in a new place of living (Małek, 2011).

The role of women in migration movements has been depreciated for a long time, and only men were considered full-fledged migrants. To quote the American sociologist, Saskia Sassen, researchers did not notice women, and most of the scholars took the ap- 
proach of an exclusionary narrative (Sassen, 2007).

Mirjana Morokvasic, who analyzed the literature from the point of view of women's presence in the narrative, points out that women in the literature on migration were only mentioned in the context of studies on family. The assumption was that, unlike the presence of men, presence of women had no significant influence on the economy of the host country (Morokvasic, 2003). The existing analyses on the topic of migration were focused on descriptions of people's movements in general (the mainstream) or from the perspective of migrating men (the malestream). The authors of numerous publications state that the essence of a comprehensive description of the issues of contemporary migration is utilizing the compensatory approach which treats the perspectives of both genders as equally important and notices the fragmentary nature of existing analyses, resulting from limited knowledge on the migrating women (Slany, 2008).

Development of feminist thought and simultaneous changes in various areas of social life - the shift towards individualism and rejection of traditional cultural standards, values, and norms - all led to driving attention towards women as a topic worthy of research (Slany, 2008). The changes were also important in leading to recognition of women's role in the migration processes (Slany, 2010). The studies conducted in the 1980 s are considered to be the moment when the female perspective was included in migration analyses. The basic question asked by researchers was whether migration influences traditional roles that women are usually burdened with (Boyd \& Grieco, 2003).

The number of migration paths is visibly increasing. It is often said that female players dominated untraditional migration directions. It turns out that as long ago as 1885, Ernest George Ravenstein wrote that women are more migratory than men (Praszałowicz, 2010). According to Ravenstein, the category of gender cannot be omitted in an analysis of migration processes. Still, it is a relatively new practice to use it as an important variable.

The increase of women's role in the construction of international money transfers is one of the elements in favor of their rising relevance in migration streams. The source of such a state of affairs is considered to be the constantly increasing role of strongly feminine occupations - the pink-collar workers (Lutz, 2008). What is being pointed out as an argument supporting it is the visibly growing tendency of women moving, the development of independent women having professional careers and the popularization of hedonistic culture (Pawlus, 2008). The growing interest of researchers in the migration of women is dictated by the variety and dynamism of changes happening within them. In the context of economic migration, some researchers talk of migration paths being used by women as a way of emancipating themselves. An argument in favor of this is women's adoption of the role of supporting the family. Many female migrants experience redefinition of their traditional role of a mother and wife in situations where they become responsible for supporting their family and providing a stable financial background (Szczygielska, 2013).

According to Zofia Kawczyńska-Butrym, women's migration is characterized by its distinct character and the exceptionally wide spectrum of motivations female migrants have. The author underlines the importance of migration for themselves in the contemporary migration movement of women. She lists four possible ways that female migrants follow nowadays (Kawczyńska-Butrym, 2009).

The first one the author describes as chasing high society, also understood as an escape from the provincial life their families live and they grew up with. The female migrants are aware that achieving the goals they set for themselves will not be possible if they do not leave their home.

Another face of migration is its educational or professional character. The female migrants aspire to gaining access to proper education and then a job that will be adequate for their qualifications and aspirations. Migration is treated in such a case as a way of personal development.

Female migrants also relatively often practice leaving in search of a partner of a different nationality. They are aware of existing laws making legal, long-term stay in the host country easier. Marrying a citizen of their new country often stabilizes their situation and makes it easier (and sometimes possible at all) to find a job for themselves. Marriage is then a strategy for securing a certain way of living (Kawczyńska-Butrym, 2009).

The author also lists a migration strategy designed to connect families again (after separation caused by one family member moving). Usually it is female migrants who join their family, partners (husbands), and sometimes friends living abroad (Kawczyńska-Butrym, 2009).

\section{ON THE ESSENCE OF GENDER IN RESEARCHING MIGRATION}

In the analysis of the migration movements of contemporary migrants, the personal (micro) level is included and their experiences and motivations are considered, as well as the communities the female migrant relates with, the country she leaves and the country she moves to. To properly understand the relation between migration and gender, it is necessary to remember about the category of gender throughout analysis of all the above-mentioned levels (Pawlus, 2008).

Pierrette Hondagneu-Sotelo in her analysis of published works on migration presented three stages of development of research on migration, including 
female perspective in her consideration. The first stage - women and migration - includes research and publications taking into account the female perspective and comparing them to the approach taken by the opposite gender. In the next stage - gender and migration - what is considered important is the presence of gender roles in migration processes and how their shape changes in a specific cultural context. The last stage, the closest to contemporary analysis, considers the notion of gender as a constitutive element of immigration. It is then seen as a gendered social process (Hondagneu-Sotelo, 2003).

Many researchers consider whether migration processes have a specific gender. The question here really is how different the experiences of migrants are depending on their gender. Are male and female experiences comparable? Or are they distinctly different? Which gender dominates the migration processes? Do both genders follow the same paths? John Berry stresses that the category of gender is one of the determinants forming the acculturation in the host country. The standards formed in the process of socialization, present and accepted in each society, migrate along with each person and are then confronted with new and often contradictory standards and expectations regarding femininity and masculinity in the social reality of the host country (Grzymała-Moszczyńska, Kwiatkowska, \& Roszak, 2010).

Gender is a relatively new variable in describing migration processes. The changes and shifts in the perception of the social world that took place in the 1960s, influenced by revolutionary social movements, including the second wave of feminism, demanded formation of new and redefining the old normative and cognitive systems. The transformations happening within the job market and supply of specific occupations and workers fundamentally increased the visibility of women in many areas of life, including migration (Slany, 2010). According to Izabela Szczygielska, "new trends, ideas and globally changing job markets push women away from the orbis interior, moving them out of traditional forms of social life, forming new ways of defining and thinking about their identity" (Szczygielska, 2013, p. 9). The growth of migration movements and women's studies conducted on their basis led to revolutionizing the way not only women's lives but also social life as a whole are studied (Małek, 2011).

The anthropologist Pierrette Hondagneu-Sotelo is considered to be one of the pioneers of including a gendered perspective in research on migration. The inclusion of gender as a category in her work led to swift development of the term and its increased usage in the context of human migration. During a meeting of the American Ethnological Society in 1996, for the first time there was a session organized with the elements of gender and international migration. In an article published after the gender panel, the topics covered included transnational maternity, problems of families experiencing separation and the situation of women redefining the traditional role of a mother and wife assigned to them by the society (Hondagneu-Sotelo, 1994).

To properly understand the presence of gender as a category in migration processes it is necessary to look at the definition of the term. According to the authors of the Sociological Dictionary, Krzysztof Olechnicki and Paweł Załęcki, "gender is socially and culturally constructed personal identification with a specific gendered role, tied with specific standards for femininity and masculinity in a society" (Olechnicki \& Załęcki, 1997, p. 154). Following the definition proposed by the author of the Dictionary of Feminism Theory, it is human communities that form gendered behaviors and norms. Gender has a substantial influence over each area of a person's life. It is the paradigm for the system of meanings, ruling how men and women are perceived in a society (Humm, 1993). And then there is Rhacel Salazar Parrenas (online), who sees gender as the category exposing differences between femininity and masculinity.

Bogumiła Lisocka-Jaegermann described the migration of Caribbean women and formed the definition of gender: Gender is a social-cultural category, consisting of socially assigned roles, related to standards for masculinity and femininity. The roles determine social, spatial, and economical behaviors, influence the identity of persons and are inscribed into the hierarchy of power and control on micro- and macrosocial scales (Lisocka-Jaegermann, 2005). Anna Titkow, who researches women and family, defines gender as a cultural superstructure of biological sex, connected with defined standards of masculinity and femininity. She also considers the processual nature of gender to be of great importance. Gender means a continuous process. It is subject to change in time and is formed within a specific cultural context. It is not once given and prescribed; it is fluid, dynamic, relative and performative. It changes under the influence of interactions between persons and their cooperation, conflicts and struggles, as well as confrontations with their past (Titkow, 2007).

As opposed to sex, which is constant and characterized by high resistance to change, gender is formed in specific social, cultural, and historical conditions. Specific standards, expectations regarding behaviors as well as defined standards for masculinity and femininity vary within societies. All these elements are created by people interacting with each other. The category of gender is not constant and fixed - it is constantly constructed and reconstructed socially (Boyd \& Grieco, 2003).

The relation between gender and migration cannot be omitted in analysis of women's migration. Because migration can radically change traditionally understood femininity and the social roles traditionally ascribed to women, ripping the stiff corset bind- 
ing them with the world of their homeland, depending on whether the female migrants are proactive or reactive, they often either uphold or drastically change their gender patterns (Slany, 2008).

The processual dimension and temporary changeability characterizing gender are extremely important aspects in the context of migration analysis. During their migration, female migrants experience those changes on two levels - within their own culture and apart from it. The relationship between culturally created gender and migration movements are primary elements of female migration because migration and gender influence one another in reforming the old, domesticated social world (Węgrzyn, 2010).

\section{MIGRATION PATHS FROM POLAND TO NORWAY}

Opening the borders of many European Union countries and including Poland among its member states systematically changed the Polish migration paths. Despite the fact that Norway is not a member of the European Union, it is one of the most popular and attractive destinations for Polish citizens. Especially popular are the southern regions of Norway. The greatest number of Polish citizens in Norway is noted mostly in the capital of one of the districts of the country - Rogaland - where the migrant community lives mostly within two cities: Stavanger and Sandnes. According to the latest data from Central Bureau of Statistics in Norway (SSB), in the last year (2013) 10,502 Polish citizens moved to Norway. This means they have reached a number greater than Lithuanians, the second biggest national group of immigrants to Norway. Central Bureau of Statistics has been collecting detailed data from the moment Poland joined the European Union and noticed an increased influx of Poles into Norway (Friberg, 2012). As of $1^{\text {st }}$ of January 2012, there are over 60000 Polish citizens living in Norway (of which one-third are women). Since May 2004, 97,498 Polish citizens have emigrated to Norway (which constitutes $15 \%$ of the overall immigration to Norway, including citizens of all the countries in the world during 2004-2013). Additionally, in this period Poles were the biggest group of immigrants in each year (according to the Polish Embassy in Oslo). Poles are now the biggest group of immigrants in over 200 Norwegian municipalities. The report of the Ministry of Foreign Affairs on the situation of the Polish community abroad and emigration states that the general standard of living, security and ease of arranging everyday business all point in favor of Norway as the destination for the place of living and work. The highly developed social support system, social security and welfare state allow for easy adaptation of migrants (Ministry of Foreign Affairs, 2009).

\section{PARTICIPANTS AND PROCEDURE}

Despite the increasing number of attempts at creating a qualitative description of contemporary migration patterns, the qualitative aspect is still at the center of researchers' attention. Considering the non-representative results of the qualitative research process, the proponents of this method face additional difficulties. Luckily, the goal behind the qualitative analyses (being understanding and satisfactorily describing mechanisms ruling the researched phenomena) helps to appreciate the benefits and values resulting from such research. Many researchers are aware that the data gathered by the qualitative method is often a valuable addition to quantitative data. Qualitative methods are supposed to help understand the processes and meanings, whereas the proponents of the approach are trying to find sense and interpret specific phenomena in categories of meaning assigned to them by people (Górny \& Koryś, 2009).

Often the migration to Norway is spoken of as highly masculine, and existing publications are mostly focused on presenting the migration statistics and the economic aspects of migration. Beyond that, reading publications on migration of the male gender one can mostly see descriptions of uneducated workers performing manual labor. The existing studies on migrating women mostly describe stories of women working abroad as housekeepers, nannies or caretakers of elderly citizens (Coyle, 2007). Those jobs are usually an extension of the roles performed in their home countries (for example Kindler \& Napierała, 2010). Reading the existing literature, it is easy to observe there is little to no space devoted to description and analysis of migrating women who obtained higher education and work in areas other than the domestic in the host country.

Deciding to write a paper on the topic of migration, it was important to consider and present voices of women who treated migration as a personal project - women who see migration as a way to develop themselves, to obtain a better job, suited to the female migrant's aspirations, achieving a certain level of independence and a feeling of success. It was important to tell the stories of women who migrate for themselves. I was also interested in seeing how the context of the host country forms female migrants and what their life in Norway looks like.

In the study I carried out ten in-depth qualitative interviews. Interviews were conducted both via Skype and face to face. All the respondents were Polish migrant women living in different parts of Norway (Oslo, Stord Island, Stavanger, Larvik, Bodø, Tromsø) with their Norwegian partner. My group of respondents was diverse in terms of migrant's age (from twenty-five to forty-four), time of residency in the host country (from one to over twenty years), educational background and occupation. Those chosen criteria 
elicited women's stories filled with a variety of motivations and numerous aspects of migration processes. In the chosen sample there was only one woman who stayed in a relationship with a Polish partner.

Each interview began with a personal, biographical narrative of the female migrant. The biographical element facilitated the analysis of important processes and events that have shaped the migrants' lives. The researcher was given an insight into what the migrants deem the most important for themselves (Harding, 2006). Each story of a migrating individual is in its own way original and unique. Using indepth interviews helped to capture this uniqueness. "There is not a single female migrant; there are multiple female migrants with varying experiences, motivations, and ambitions, numerous ways of living abroad; and analyzing each community brings something new and unique" (Małek, 2011, p. 46).

The first part of the script had an exploratory character and was not strictly structured. It led to a sense of flexibility for the interviewees. In order to gather elements which would connect each individual migration project, a section of the script was partially structured. The second part of the script consisted of blocks of questions regarding: the origins of migration, the migration's trajectory, reasons for migration, contacts with family in Poland, private and professional life in Norway, relations in Norway, the process of learning the new culture and language, strategies of achieving fulfillment and plans for the near future.

\section{RESPONDENTS’ PROFILES ${ }^{1}$}

1. Izabela (Oslo), age 28, comes from Gdańsk, has been in Norway for three years. She left Poland as an academic exchange student. She graduated from the Scandinavian Faculty at the University of Gdańsk. Iza is a professionally active woman and has a variety of experience working in the Norwegian environment (while staying in Norway she has changed her workplace several times). She does not plan to go back to Poland. For two years she has been in a partnership with a Norwegian man. This couple has no children.

2. Patrycja (Stord Island), age 31, married, comes from Gdynia. Patrycja is a mother of two sons. She met her husband in Poland, when he worked for a short period in a Polish company. Patrycja decided to move to Norway when her future husband finished the project, mostly because they both could not imagine a long distance relationship. During the interview Patrycja admitted that her husband made her fall in love with Norway and she decided to leave Poland.

3. Elżbieta (Oslo), age 25, comes from Poznań. Elżbieta has lived in Oslo for one and a half years. She graduated from the University of Poznań. She is now working as a maid in a hotel. She is a single woman currently, but she has previous experiences of being in a partnership with a Norwegian man. After her stay in Norway, as an exchange student, she decided to move permanently. Elżbieta claims that she is very pleased with her decision and believes that Norway is her home now.

4. Hanna (Oslo), age 35, has lived in Oslo for one and a half years. She has been in a long distance relationship with a Norwegian widower for seven years. Recently, she moved in to his place and they live together with his 16-year-old daughter. Hanna is currently unemployed. She graduated from the Faculty of Psychology at the University of Wroclaw. She is learning the Norwegian language and looking for a job in her profession in Oslo.

5. Katarzyna (Oslo), age 31, married, comes from Gdynia. Katarzyna has a four-year-old son. She came to Norway six years ago, together with her Norwegian fiancé. They met on holiday in Spain. After a year of being a couple they decided to move to Oslo. Katarzyna is a linguist and is preparing for the exam for sworn translators in Oslo. She reached a very high level in the Norwegian language extremely quickly. She is currently working as a freelance translator. She claims that when she became pregnant she finally found her place in Norway.

6. Dorota (Larvik), age 28, lives in Larvik together with her partner. She is the only interviewee who is in a relationship with a Polish man. Dorota graduated from the Faculty of Psychology at the University of Wrocław. She came to Norway on her own, fascinated by its nature and views. After two years her boyfriend joined her. Dorota is currently on leave of absence, but has so far been active professionally. She is looking for a job that would meet her expectations and be consistent with her education.

7. Paula (Bodø), age 36, came to Norway around ten years ago. She is studying, together with her Norwegian partner. She works in the evenings as a barmaid. She remembers that taking her first steps in Norway was a difficult period in her life. She has a nine-year-old daughter. She claims that the decision to settle in Norway came very spontaneously and quickly. She cannot imagine her life in Poland.

8. Julita (Tromsø), age 44, married, comes from southern Poland. Julita has been in Norway for the longest period of time - over 20 years. She has two children - a daughter and a son. Her children speak mostly Norwegian. She remembers her departure as unplanned and sudden. Despite initial concerns, related to her permanent stay in Norway, very quickly she realized she could not imagine her life in any another location. She lived in Oslo for several years. Together with her hus- 
band she settled in northern Norway around ten years ago.

9. Karolina (Stavanger), age 33, engaged. She has a twelve-year-old son from a previous relationship. They have lived in Norway for three years. One and a half year ago Karolina met her Norwegian partner. They bought a house recently, which is located near Stavanger. Karolina got a job as a consultant in IT. Just after moving to Norway she worked as a taxi driver. She has been engaged since January 2014.

10. Marta (Stavanger), age 27, moved to Norway in December 2011. For more than half a year she has been in a relationship with a Norwegian man. She claims that the decision to leave Poland was not difficult for her because she knows there is always home and family to go back to. Marta is an employee in a big canteen. She is still working on her Norwegian language skills. She graduated from the Faculty of Tourism and Leisure at the University of Białystok. Marta is constantly trying to get a job in her profession.

\section{OUTCOMES AND CONCLUSIONS}

The dictionary of the Polish language defines emancipation as freeing individuals or social groups from social dependence and obtaining a better position in the social structure. The basic and most common use of the word brings to mind the process of women gaining access to many areas of public life. Associations to this term relate mostly to organizations founded by women, whose representatives have initiated various movements for the betterment of women's situation. However, the term does not need to describe only radical undertakings. Krystyna Slany, writing about the stiff, cultural corset being ripped by migrants, is referring to the situation of freeing yourself. The author maintains that migration is a process that influences change of gendered standards. Migration, understood as a great social change, breaks, temporarily or permanently, the organized world of social order, canonical for women, and constructs it anew (Slany, 2008). The process of female migrants freeing themselves was made visible also in the narratives related by the women interviewed during the research. In some cases the interviewees spoke of it directly, but more often the change was described indirectly. In the conducted interviews, only one female migrant directly pointed to the glass ceiling she encountered while trying to advance her career in Poland, and which disappeared after merely two years of living in Norway.

"I'd been working very actively, trying to make a career, but like most women in Poland I met a kind of glass ceiling, so I couldn't go further. It was years in the same position without the possibility to do anything else, without the possibility to get a job in my profession, which is IT, and it's very hard for woman to get. So yeah, there was nothing keeping me in Poland and my sister said: Hey with your education? You can just get any job you want here, just come on! So I did. It took one and a half years to get a proper job, a dream job, but I got it. I wouldn't have it in Poland, ever" (Karolina, age: 33).

To other Polish women, migration helped in reformulating the expectations they were facing within the communities they lived in. Some of them were certainly the result of the high standards they set for themselves. It might seem that the friendly surroundings of the host country would help them be more lenient and kind towards themselves, but that does not mean they did not have any expectations for themselves. Socially constructed identification of an individual with a specific gender role, tied with set standards of femininity and masculinity present in a society, was in a way made from scratch by the migrating women (Olechnicki \& Załęcki, 1997). The migration became a tool for the migrating women to see their lives from a new, fresh perspective. A perfect example of assuming a new point of view is the following quotation from an interviewee:

"Yes, I feel independent. And that's a great explanation for why I feel like I'm at home here. I'm independent on every level. I have this feeling that everything that happens in my life... depends in one way or another on something I have done. I decide how much energy I put into something I want to achieve. You want to have a family - you start a family, you want to study - the state helps you, you want to do whatever - you can do that, you want to get into an occupation - there is a great chance you can, you want to travel the world - it's only a matter of time before you do. In Poland I felt terribly constricted. Some things were just outside of the world you lived in" (Paula, age: 36).

In an analysis, one should not omit the changes in the economic area of life achieved thanks to migration that made Polish women achieve a better financial background, giving them the sense of security, peace, fulfillment and independence. When comparing the situation before and after migration, without a doubt they point to a higher comfort of their current situation over their lives before migration.

"Undoubtedly, the salaries are much higher in Norway, and when you get a job, I think the job security is much higher than it was in Poland. When speaking about financial security, (...) I'd never want to live in Poland, working in Poland for a Polish employer. I used to think there wasn't anything wrong with that but now, and it's about more than money, it's more about communication with Polish and Norwegian employers, it's like Heaven and Earth. Now, I can't imagine working for a Polish employer" (Patrycja, age: 31 ). 
Indirect freedom from the standards set by the surrounding communities is relevant in a situation where the interviewed women consciously give up some of their responsibilities and do not feel the need to perform them regardless of the situation, and certainly not at the cost of their health and mental well-being. In all the interviews there was a moment where the Polish women stressed that living in Norway taught them to be at peace with themselves, have some distance to themselves and others as well as their expectations, and to stop worrying about insignificant details. Their narratives suggest that their old approach to the expectations set for them by themselves and by others would not allow them to follow their current approach to life. The rush of Polish life and the pressure to always do everything your best is not applicable to life in a Scandinavian country, and that seems to make the migrants happier.

"I never felt quite well in Poland. I realized that only after I'd lived in Norway for some time and it turned out that I feel here much more at home. Everything done here is so peaceful. There is this sense of equality. I mean, in Poland everything is organized hierarchically... I was born to live in a much more equal system. I don't need to prove anything to anyone, I can just be myself. Nobody is judging me. It doesn't matter what sort of university I graduate from or what degree I get. There's less stress and less pressure. There's still a lot of ambition but there isn't so much pressure" (Paula, age: 36 ).

"Norway gave me... the possibility of developing myself, independence, great opportunities for improving my English and Norwegian. The financial possibilities, high salaries and a different outlook on life... with much more distance and peace. They don't get stressed over little things here... what else I learned is a bit of healthy selfishness (...). I learned to be quiet and peaceful" (Elżbieta, age: 25).

One of the migrants illustrated the described situation using a recent example from her life, one that was very relevant to the process of freeing herself:

'The old Patrycja, for instance, was the kind of person who would have a new cabinet like me, just brought from the store. It's downstairs, I need to make space for it and get rid of a lot of stuff to make room for it, clean it, et cetera. The old Patrycja would be dead tired but she would be still standing and cleaning, while the new Patrycja has learned here in Norway not to exert herself like that because to relax is just as important; a relaxed and rested person is a happy person, they really live their lives like that and there's so much good about that, so the new Patrycja, having lived in Norway for 6 years, left this cabinet, it's been standing there since Saturday and I think I'll get it set up sometime this week, but I'm not exhausted and I will not have the cabinet set no matter what. When I'm tired, I am tired and I go to bed and I can take care of it later" (Patrycja, age: 31 ).
On the basis of the statements given by female migrants, one can reason that the migration project was the source of their metamorphosis. Women realized they had strength and could deal well with stressful situations caused by living in a foreign country. Even if they have the support of a partner, they still need to solve some problems on their own. Undoubtedly they need to confront the things their intuition suggests they should do. The female migrants also understand that they can change what others expect from them (and what they expect from themselves) and it does not need to mean sacrifices on their own part. Even more so, such change seems to bring nothing but gain. All of these stories prove that travel educates and migration projects may significantly influence reformulation of the world and social order, creating it anew in a new social reality.

\section{SUMMARY}

The main goal of the research was to understand the world of Polish women who migrated to Norway. Each story was treated as a unique and separate narrative, uncovering various regularities and dependencies of this world. In interviews with the female migrants, a rule was made to treat sidetracking the conversation as a supplement to the knowledge gathered, describing everyday life in Norway. Therefore, during the interviews I let the interviewees go off topic. This strategy led to gathering data of a higher quality. The interviews are a systematic base of information that I have yet to utilize in full. For this paper, only part of the gathered empirical data has been used.

The basic question I wanted to be able to answer even before I started writing the paper was whether (and if so, how much) the migrating Polish women see their migration as a strategy for emancipation. In my approach I needed to learn whether women who migrate gain a higher level of social and financial independence; whether life in Norway, with a Norwegian partner, results in change of specific behaviors and expectations (of others and the migrants themselves); and whether migration modifies their frame of mind regarding the standards of femininity and the traditional roles assigned to women by society. It was important to me to capture how migration and gender relate to one another, leading to the transformation of the social world of Polish women. I found it intriguing what their life looked like after complete immersion in the Norwegian culture, and whether we could speak of a complete immersion at all.

Despite the fact that Polish women do not see direct connection between migration and freeing themselves from a stiff cultural corset, their narration supports this hypothesis. Female migrants exhibit a number of behaviors they adopted while 
living in Norway and which help them change the expectations they have towards themselves. Perhaps the term emancipation should be replaced with "indirect emancipation"?

The decision to move itself made the female migrants independent players in the migration processes, realizing their own needs and plans for life. Their independence and autonomy were affirmed at every step of the migration. The greatest trial they needed to endure was the culture shock they needed to face at the initial stages of their migration. What they all agree was the most difficult was the feeling of loneliness they had to face, which seemed even more dire in a new and different cultural context.

Execution of the migration project helped the female migrants modify the expectations they had had for themselves in the past. They were freed from the rush that ruled their lives before. They learned to live in peace and harmony. Leaving their countries helped them understand they do not need to prove anything to anyone. It helped them gain a new, fresh perspective. The stories they told confirmed that migration is a process leading to deep changes in personality, ways of thinking about oneself and relationships with others because as a result of migration, the lifestyle changes, too, leading women closer to the western standards of femininity (Małek, 2011).

The conducted research strengthened my belief that there is much to learn and discover from experiences of a single person and how valuable narratives of migrating women can be.

Interviews conducted with Polish-Norwegian couples during the PAR Migration Navigator pilot study were a great source of inspiration. The dynamics of those interviews were noticeably different from an interview conducted with a single person. I do not want to depreciate individual interviews conducted with female migrants but merely point out a couple of differences. The factor that improved the quality of coupled interviews was the fact that they were conducted in the couples' homes, allowing observation of how the partners naturally interacted, how together they reacted to some of the questions, how they talked with each other and how they handled moments of conflict. It would be beneficial to see how all the female migrants behave in a coupled interview. Including the point of view of the Norwegian partners, who are often a guide for the migrating Polish women to the Norwegian way of living (due to their familiarity with Norwegian traditions, relationships and values) may be highly interesting. From experience gathered so far it can be judged that including the partner in the narrative of migrating Polish women's experiences can make the stories richer and evoke surfacing of new threads, absent from conversations with the migrant herself. The dialogue between partners enriches the content of the stories. In some situations the role of a researcher is to moderate the conversation, leading it into the right direction and managing conflict. Sometimes the circumstances demand a great deal of sensitivity and experience on the part of researchers. Still, continuing the research, with the addition of the element of a dialogue between partners, could be valuable and cognitively attractive.

Perhaps it would be worth considering whether modern standards of migration are not mainly focused on achieving independence and pursuing complete autonomy. Supposedly, choosing Norway as the host country determines the expectations female migrants hold. It may be influenced by the social and professional roles women fulfill in Norway.

This paper was presented previously during $10^{\text {th }}$ International Conference "Woman in Culture: Gender, Culture \& Migration" held at University of Gdansk, Poland, in March 2015. The conference was co-funded from Norway Grants in the Polish-Norwegian Research Programme operated by the National Centre for Research and Development.

This research refers to the main master degree thesis, based on qualitative research conducted both during master degree research and the pilot study of the sociological, non-commercial research PAR Migration Navigator project entitled "Socio-Cultural and Psychological Predictors of Work-Life Balance and Gender Equality Cross-Cultural Comparison of Polish and Norwegian Families (WLB_GE)". The research leading to these results has received funding from the Polish-Norwegian Research Programme operated by the National Centre for Research and Development under the Norwegian Financial Mechanism 20092014 in the framework of Project Contract No. PolNor/202343/62/2013.

\section{ENDNOTES}

1 All the names of the respondents have been modified by the author.

\section{RefERENCES}

Bokszański, Z. (2007). Encyklopedia socjologii [Encyclopedia of Sociology]. Warszawa: Oficyna Naukowa.

Boyd, M., \& Grieco, E. (2003). Migration fundamentals - women and migration: incorporating gender into international migration theory. Migration Information Source. Retrieved from http://www.migrationinformation.org/Feature/display.cfm?ID=106

Coyle, A. (2007). Resistance, regulation and rights. The changing status of Polish women's migration and work in 'new' Europe. European Journal of Women's Studies, 14, 37-50. 
Friberg, J. H. (2012). The Polish worker in Norway. Emerging patterns of migration, employment and incorporation after EU's eastern enlargement. $\mathrm{PhD}$ Dissertation, Oslo.

Górny, A., \& Koryś, I. (2009). O pożytkach podejścia jakościowego w badaniu migracji międzynarodowych. Studia migracyjne. Przegląd polonijny [Benefits of a qualitative approach in the study of international migration. Migration Studies Polish Diaspora Review, no. 1.] (pp. 27-45). Warszawa: Polish Academy of Social Sciences.

Grzymała-Moszczyńska, H., Kwiatkowska, A., \& Roszak, J. (2010). Drogi i rozdroża. Migracje Polaków w Unii Europejskiej po 1 maja 2004 roku. Analiza psychologiczno-socjologiczna [Roads and crossroads. Migration of Poles in the European Union after the 1st May 2004. Psychological and sociological analysis]. Kraków: Nomos.

Harding, J. (2006). Questioning the subject in biographical interviewing. Sociological Research Online, 11, 3.

Hondagneu-Sotelo, P. (1994). Gendered transitions: Mexican experiences of immigration. London: University of California.

Hondagneu-Sotelo, P. (2003). Gender and U.S. Immigration: Contemporary Trends. Berkeley \& Los Angeles: University of California Press.

Humm, M. (1993). Stownik teorii feminizmu [Dictionary of Feminists' Theory]. Warszawa: Semper.

Kawczyńska-Butrym, Z. (2009). Migracje i wybrane zagadnienia [Migration and selected issues]. Lublin: Wydawnictwo Uniwersytetu Marii Curie-Skłodowskiej.

Kubitsky, J. (2012). Psychologia migracji [Psychology of migration]. Warszawa: Difin.

Kindler, M., \& Napierała, J. (2010). Migracje kobiet. Przypadek Polski [Women in migration. Polish example]. Warszawa: Wydawnictwo Naukowe Scholar.

Lisocka-Jaegermann, B. (2005). Migracje kobiet karaibskich [Migration of Caribbean women]. In: J. E. Zamojski, Kobiety i mtodzież w migracjach. Migracje i spoteczeństwo. Vol. 10 [Women and youth migration. Migration and Society, vol. 10] (pp. 147-176). Warszawa: Neriton.

Lutz, H. (2008). Gender in migratory process. Conference on Theories of Migration and Social Change. St. Ann's College, Oxford, England, 1-3 July 2008.

Małek, A. (2011). Migrantki opiekunki. Doświadczenia migracyjne Polek mieszkających w Rzymie [Migrant nannies. Migratory experiences of Polish women living in Rome]. Kraków: Wydawnictwo Uniwersytetu Jagiellońskiego.

Ministry of Foreign Affairs. (2009). Raport o sytuacji Polonii i Polaków za granica [Raport on the situation of the Polish Diaspora and Poles abroad] (pp. 186-187). Warszawa: Ministry of Foreign Affairs.

Morokvasic, M. (2003). Transnational mobility and gender: a view from post-wall Europe. In: M. Mo- rokvasic, U. Erel, \& K. Shinozaki (eds.), Crossing Borders and Shifting Boundries. Gender on the Move (pp. 101-133). Opladen: Leske + Budrich.

Niedźwiedzki, D. (2010). Migracje i tożsamość. Od teorii do analizy przypadku [Migrations and identity. From theory to the case study]. Kraków: Nomos.

Olechnicki, K., \& Załęcki, P. (1997). Stownik socjologiczny [Dictionary of Sociology]. Toruń: Graffiti BC.

Parrenas, R. S. (online). Inserting feminism in transnational migration studies. http://www.migrationonline. cz/ en/inserting-feminism-in-transnational-migration - studies. Online access: 26.05.14.

Pawlus, M. (2008). Migracje kobiet [Women in migration]. In: J. Balicki, Migracje jako nowa kwestia spoteczna [Migration as a new social issue] (pp. 41-50). Katowice: Księgarnia św. Jacka.

Praszałowicz, D. (2010). Polacy w Berlinie. Strumienie migracyjne i spoteczności imigracyjne. Przeglad badań [Poles in Berlin. Migration streams and immigration communities. Research Overview]. Kraków: Księgarnia Akademicka.

Sassen, S. (2007). Globalizacja. Eseje o nowej mobilności ludzi i pieniędzy [Globalization and its discontents: essays on the new mobility of people and money]. Kraków: Wydawnictwo Uniwersytetu Jagiellońskiego.

Slany, K. (2008). Migracje kobiet. Perspektywa wielowymiarowa [Migration of women. Multidimensional perspective]. Kraków: Wydawnictwo Uniwersytetu Jagiellońskiego.

Slany, K. (2010). Kobiety imigrantki w Polsce. Perspektywa genderowa [Immigrant women in Poland. Gender perspective]. In: Drogi i rozdroża. Migracje Polaków w Unii Europejskiej po 1 maja 2004 roku. Analiza psychologiczno-socjologiczna [Roads and crossroads. Migration of Poles in the European Union after the $1^{\text {st }}$ May 2004. Psychological and sociological analysis] (pp. 223-238). Kraków: Wydawnictwo Uniwersytetu Jagiellońskiego.

Statistisk Sentralbyra. (2014). Poles as the largest immigrant group in Norway in 2013. Retrieved from: https://oslo.trade.gov.pl/pl/aktualnosci/article/ y,2014,a,44687,Polacy_najliczniejsza_grupa_imigracyjna_w_Norwegii_w_2013_r.html.

Szczygielska, I. (2013). Migracje zarobkowe kobiet $i$ ich wptyw na funkcjonowanie rodzin [Economic migration of women and their impact on the family functioning]. Warszawa: Wydawnictwo Uniwersytetu Jagiellońskiego.

Titkow, A. (2007). Tożsamość polskich kobiet. Ciggtość, zmiana, konteksty [The identity of Polish women. Continuity, change, contexts]. Warszawa: PAN.

Węgrzyn, D. (2010). Polki w Macedonii. Miłosna emigracja - życiowe zmagania: walka, uległość, ucieczka [Polish women in Macedonia. Love emigration-life's struggles: the struggle, submission, escape]. Migration Studies - Polish Diaspora Review, 1, 141-142. 